ISSN 1392-3196 / e-ISSN 2335-8947

Zemdirbyste-Agriculture, vol. 103, No. 4 (2016), p. 405-410

DOI 10.13080/z-a.2016.103.052

\title{
Effects of cucumber grafting on yield and fruit sensory characteristics
}

\author{
Nikolay VELKOV, Galina PEVICHAROVA \\ Maritsa Vegetable Crops Research Institute \\ Bersovsko 32, 4003 Plovdiv, Bulgaria \\ E-mail: velkov_n@abv.bg
}

\begin{abstract}
During the period 2014-2015 the effects of cucumber grafting on yield and fruit sensory characteristics were studied under glasshouse conditions. Three long type parthenocarpic cucumber cultivars were grafted on five cucurbit rootstocks. The aim of the study was to compare the yield, elements of productivity and fruit sensory characteristics in order to establish the most appropriate scion/rootstock combinations. The highest yield was recorded in combination cv. 'Kiara $\mathrm{F}_{1}$ ' grafted on Cucurbita maxima $\times$ C. moschata $\mathrm{F}_{1}$. Rootstocks of Lagenaria and C. maxima and control treatments showed great earliness of cucumber scions. C. maxima $\times$ C. moschata $\mathrm{F}_{1}$ rootstock induced the highest fruit number per plant. The effect of rootstock on fruit quality showed a significant variation in the value of sensory traits appearance, aroma, taste and total sensory evaluation depending on the scion and rootstock combinations. C. maxima $\times C$. moschata $\mathrm{F} 1$, Lagenaria and $C$. maxima rootstocks demonstrated good compatibility with the studied cucumber cultivars. The choice of combinations between scion cultivar and rootstock species should be determined after preliminary studies of both components.
\end{abstract}

Keywords: appearance, Cucumis sativus, fruit number, fruit weight, taste, texture.

\section{Introduction}

Grafting Cucurbitaceous crops is applied in the agricultural practice for protection of plants from soil-borne pathogens and nematodes. This problem has become world-important since 2005 when the application of methyl bromide was prohibited (Lee et al., 2010). Intensive use of agricultural land and monoculture growing results in a rapid multiplication of soil-borne pathogens and nematodes. This concerns mostly the vegetables grown in greenhouse conditions (Lee, 1994). On the other hand, grafting is applied when it is necessary to induce tolerance to high or low soil temperature, salt stress and heavy metal contents in the soil. These problems can be prevented by grafting on the appropriate rootstocks (Huang et al., 2010; Schwarz et al., 2010; Colla et al., 2012).

Cucumber is the second most important crop in greenhouse production in Bulgaria. As a result of the above mentioned problems, the production areas have been decreased (Agrostatistic, 2014). In this relation, grafting on cucurbit rootstocks is one of the adequate decisions. Cucumber can be grafted on different cucurbit crop rootstocks (Cucurbita maxima, C. moschata, C. ficifilia, Lagenaria spp., Luffa spp.). The hybrid C. maxima $\times$ C. moschata $\mathrm{F}_{1}$ is the most widely used rootstock (Oda, 2002; Davis et al., 2008 a; Sakata et al., 2008).

Numerous studies have demonstrated that the grafting had positive effects such as increase of plant vigour, yield, earliness and tolerance to stress conditions (Pavlou et al., 2002; Huang et al., 2009; Cansev, Ozgur, 2010). These characteristics depend mostly on the genotype of rootstock (Uysal et al., 2012). Moradipour et al. (2010) have showed that the type of rootstock had a significant effect on the yield and other growth characteristics. The cucumber grafting on different rootstocks reduces precocity, but the total yield increases significantly compared to the non-grafted treatment (Hoyos, 2001).

It was established that grafting had some negative effects such as deterioration in taste, changes in the fruit colour, enlargement of fruit size. The fructose content and sweetness of cucumber fruits are increased when the plants are grafted which indicates the significance of rootstocks (Lee et al., 1999). The collar size of the grafted plants varies depending on the rootstock. Usually, the diameter of the collar of the grafted plants is greater (Hoyos, 2001).

There are some uncertainties concerning scion, rootstock and environment interactions. According to Sakata et al. (2007), the best choice for a rootstock depends on the production area, rootstock species and scion cultivars used under different conditions. Davis et al. (2008 b) mentioned that rootstock/scion combinations should be carefully selected for specific climatic and geographic conditions. The appropriate selection could help to control the soil-borne diseases, increase yield and improve fruit quality.

The data available demonstrate the importance of the optimizing of rootstock/scion combinations. This motivates us to carry out a more detailed study of these significant parameters such as yield, earliness, taste and some fruit sensory characteristics of grafted cucumber plants on different cucurbit rootstocks. The aim of this study was to evaluate the yield, elements of productivity and fruit sensory characteristics of grafted and non-grafted cucumbers in order to establish the most appropriate scion/rootstock combinations. 


\section{Materials and methods}

The experiment was carried out during the period 2014-2015 in an unheated glasshouse with a North-South aspect in the Maritsa Vegetable Crops Research Institute (VCRI), Plovdiv, Bulgaria.

Plant material and grafting techniques. Three cucumber (Cucumis sativus L.) F $\mathrm{F}_{1}$ cultivars 'Kiara', 'Mina' and 'Mirey' (Maritsa VCRI) were used as scion. Five rootstocks from different species Luffa cylindrical Roem. (landrace), Lagenaria siceraria Standl. (landrace), Cucurbita maxima Duch. ('Plovdivski', old local cultivar), Cucurbita moschata Duch. ('Moskatna 51-17', old local cultivar) and C. maxima $\times$ C. moschata $\mathrm{F}_{1}$ (cv. 'Carnivor', Syngenta Ltd.) were used. Scion seeds were sown five days before all rootstocks seeds and the tongue approach grafting method was used (Lee, 1994; Davis et al., 2008 a). Rootstock had fully developed cotyledons and the scion had cotyledons and the first true leaf. The rootstock and scion were cut through the hypocotyl at a $35^{\circ}$ to $45^{\circ}$ angle. The rootstock was cut downward halfway through the hypocotyls and the scion upward in length of $1.5 \mathrm{~cm}$. Both parts were put together and held by aluminium foil. Rootstock was removed five days after grafting. The scion hypocotyl was cut off seven to ten days after grafting at just below the graft union.

Conditions of the experiment. The seeds were sown on 10-15 March in perlite substrate. Grafting and pricking were done on 25-30 March in 0.5 L pots. Plants were transplanted on 20-25 April. A double-row system was used. Plant spacing was $80 \mathrm{~cm}$ between two rows followed by $240 \mathrm{~cm}$ for a walking path, $45 \mathrm{~cm}$ between plants in the rows. Plants were grown vertically in the greenhouse until plants reached the support wires $(2 \mathrm{~m})$. Harvesting was performed from 20-26 May until 20-26 July.

The soil characteristics $(0-30 \mathrm{~cm}$ layer prior transplanting) were: $\mathrm{pH}-6.7$, electrical conductivity (EC) $-0.14 \mathrm{mS} \mathrm{cm}^{-1}, \mathrm{NO}_{3}-15.0 \mathrm{mg} \mathrm{dm} 3, \mathrm{P}-4.1 \mathrm{mg} \mathrm{dm} 3, \mathrm{~K}-$ $31.5 \mathrm{mg} \mathrm{dm}^{3}, \mathrm{Ca}-28.0 \mathrm{mg} \mathrm{dm}^{3}, \mathrm{Mg}-18 \mathrm{mg} \mathrm{dm}$, determined in water extract 1:2 (Sonneveld, 1990) and $0.25 \%$ total nitrogen (Kjeldahl). Nitrogenous, phosphate and potassium fertilizers were applied according to the recommendations of the Laboratory of Plant Nutrition in the Maritsa VCRI. The average temperatures during the growing seasons were around $25^{\circ} \mathrm{C}$. Relative humidity was $70-80 \%$.

Trial design. The trial was performed by a complete randomized block design in three replications,
$0.72 \mathrm{~m}^{2}$ nutrient plot per plant, ten plants per replication. Three cucumber cultivars were grafted on five rootstocks and non-grafted cucumber cultivars were used as a control treatment.

Measurements and sensory analysis. The fruits were harvested twice weekly. The yield, earliness (sum of the first five harvests) and parameters of productivity (average fruit number per plant and fruit weight) were established for all plants from the experiment. The sensory analysis was carried out on the traits: appearance, fruit colour before cutting, flesh colour, aroma, texture, cavity presence, bitterness and taste. A five-point scale (1 - very bad, 2 - bad, 3 - medium, 4 - good, 5 - very good) with 0.25 step was used. The total sensory evaluation was formed on the basis of complete perception, but not as an arithmetic average from evaluation for individual sensory traits. The fruits were evaluated twice - at the beginning and in the middle of the season during both years. Ten fruits at technological maturity were evaluated from each treatment. Four expert-assessors participated in sensory evaluation of the fruits.

Statistical analysis. All data were statistically analyzed using the software SPSS 12 (SPSS Inc., USA). Three-way analysis of variance was applied to established significance of the studied factors (scion, rootstock and year) and their interactions on yield, earliness, average fruit number per plant and average fruit weight. The power of influence $(\eta \%)$ of factors on studied traits and their interactions were calculated (Lidanski, 1988). Duncan's multiple range test was performed at $P \leq 0.05$ on each of the significant variables measured. Cluster analysis by average linkage (between groups) was conducted to identify similarities/dissimilarities between the studied treatments.

\section{Results}

The results from the three-way analysis of variance showed great influence of the factors scion A $(P \leq 0.01)$, rootstock B $(P \leq 0.001)$ and year $\mathrm{C}(P \leq 0.001)$ on the yield (Table 1$)$. There were significant effects of interactions between $\mathrm{A} \times \mathrm{C}$ and $\mathrm{B} \times \mathrm{C}$. The character earliness was influenced significantly by factors rootstock $\mathrm{B}(P \leq 0.001)$, scion A $(P \leq 0.001)$ and interaction of the three main factors $(\mathrm{A} \times \mathrm{B} \times \mathrm{C})$. The variation of fruit number per plant was influenced significantly by rootstock B $(P \leq 0.001)$, year $\mathrm{C}(P \leq 0.001)$ and their interaction $\mathrm{B} \times \overline{\mathrm{C}}(P \leq 0.001)$.

Table 1. Three-way analysis of variance and power of influence of factors on total yield, earliness, fruit number per plant and fruit weight

\begin{tabular}{|c|c|c|c|c|c|c|c|c|c|}
\hline \multirow[b]{2}{*}{$\begin{array}{l}\text { Source of } \\
\text { variation }\end{array}$} & \multirow[b]{2}{*}{$\mathrm{df}$} & \multicolumn{2}{|c|}{ Total yield } & \multicolumn{2}{|c|}{ Earliness } & \multicolumn{2}{|c|}{ Fruit No. per plant } & \multicolumn{2}{|c|}{ Fruit weight } \\
\hline & & $\begin{array}{c}\text { mean } \\
\text { square }\end{array}$ & $\begin{array}{c}\text { power of } \\
\text { influence } \\
\eta_{0}\end{array}$ & $\begin{array}{c}\text { mean } \\
\text { square }\end{array}$ & $\begin{array}{c}\text { power of } \\
\text { influence } \\
\eta_{0}\end{array}$ & $\begin{array}{c}\text { mean } \\
\text { square }\end{array}$ & $\begin{array}{c}\text { power of } \\
\text { influence } \\
\eta_{0}\end{array}$ & $\begin{array}{c}\text { mean } \\
\text { square }\end{array}$ & $\begin{array}{c}\text { power of } \\
\text { influence } \\
\eta_{0}\end{array}$ \\
\hline Scion A & 2 & 3099844 & $1.61 * *$ & 2094444 & $5.27 * * *$ & 106 & 0.29 & 660 & 1.63 \\
\hline Rootstock B & 5 & 13033391 & $16.97 * * *$ & 5971577 & $37.56 * * *$ & 43320 & $16.51 * * *$ & 6015390 & $18.59 * * *$ \\
\hline Year C & 1 & 214133653 & $55.78 * * *$ & 124771 & 0.16 & 6 & $57.34 * * *$ & 310 & 0.05 \\
\hline $\mathrm{A} \times \mathrm{B}$ & 10 & 500436 & 1.30 & 551120 & $6.93 * * *$ & 136 & 1.10 & 1417 & $20.55 * * *$ \\
\hline $\mathrm{A} \times \mathrm{C}$ & 2 & 1760426 & $0.92 *$ & 952586 & $2.40 * *$ & 2363 & 0.65 & 0 & 1.05 \\
\hline $\mathrm{B} \times \mathrm{C}$ & 5 & 10394881 & $13.54^{* * *}$ & 3913346 & $24.62 * * *$ & 5 & $11.22 * * *$ & 783 & $15.17 * * *$ \\
\hline $\mathrm{A} \times \mathrm{B} \times \mathrm{C}$ & 10 & 567482 & 1.48 & 576172 & $7.25 * * *$ & 13 & 2.98 & 199 & 3.64 \\
\hline $\begin{array}{l}\text { Error } \\
\text { Total }\end{array}$ & $\begin{array}{c}72 \\
107\end{array}$ & 447732 & 8.40 & 174640 & 15.82 & 93 & 9.92 & 1156 & 39.38 \\
\hline
\end{tabular}

df - degrees of freedom; $*-P \leq 0.05, * *-P \leq 0.01, * * *-P \leq 0.001$

The results for the total yield, earliness, fruit number per plant and fruit weight showed significant differences between investigated treatments (Table 2). Cultivar 'Mirey $\mathrm{F}$ ' formed the highest yield after grafting on Lagenaria $\left(7.04 \mathrm{~kg} \mathrm{~m}^{-2}\right)$ and C. maxima $\left(6.91 \mathrm{~kg} \mathrm{~m}^{-2}\right)$.
The differences ware insignificant compared to the control $\left(6.31 \mathrm{~kg} \mathrm{~m}^{-2}\right)$. Cultivar 'Kiara $\mathrm{F}_{1}$ ' produced the highest yield after grafting on C. maxima $\times$ C. moschata $\mathrm{F}_{1}(7.06$ $\left.\mathrm{kg} \mathrm{m}^{-2}\right)$ and C. maxima $\left(6.97 \mathrm{~kg} \mathrm{~m}^{-2}\right)$ which exceeded the control with $27.55 \%$ and $25.94 \%$, respectively. 
Table 2. Total yield, earliness, fruit number per plant and average fruit weight values and percent compared to nongrafted treatment (control)

\begin{tabular}{|c|c|c|c|c|c|c|c|}
\hline \multirow{2}{*}{$\begin{array}{l}\text { Scion / } \\
\text { rootstock }\end{array}$} & \multicolumn{2}{|c|}{ 'Mirey $\mathrm{F}_{1}$ ' } & \multicolumn{2}{|c|}{ 'Kiara $F_{1}$ ' } & \multicolumn{3}{|c|}{ 'Mina $F_{1}$ ' } \\
\hline & value & $\%$ & value & $\%$ & value & & $\%$ \\
\hline \multicolumn{8}{|c|}{ Total yield $\mathrm{kg} \mathrm{m}^{-2}$} \\
\hline Luffa & $4.42 \mathrm{c}$ & 70.11 & $4.53 \mathrm{c}$ & 81.88 & 4.43 & $\mathrm{c}$ & 82.12 \\
\hline Lagenaria & $7.04 \mathrm{a}$ & 111.49 & $6.39 \mathrm{ab}$ & 115.47 & 6.11 & $\mathrm{a}$ & 113.32 \\
\hline C. maxima & $6.91 \mathrm{a}$ & 109.53 & $6.97 \mathrm{a}$ & 125.94 & 6.18 & $\mathrm{a}$ & 114.52 \\
\hline C. moschata & $5.77 \mathrm{~b}$ & 91.39 & $6.10 \mathrm{ab}$ & 110.20 & 5.511 & $\mathrm{~b}$ & 102.12 \\
\hline C. $\max \times C . \operatorname{mos} \mathrm{F}_{1}$ & $6.67 \mathrm{ab}$ & 105.63 & $7.06 \mathrm{a}$ & 127.55 & 6.21 & $\mathrm{a}$ & 115.16 \\
\hline Control 1 & $6.31 \mathrm{ab}$ & 100.00 & $5.53 \mathrm{bc}$ & 100.00 & 5.391 & $\mathrm{~b}$ & 100.00 \\
\hline \multicolumn{8}{|c|}{ Earliness $\mathrm{kg} \mathrm{m}^{-2}$} \\
\hline Luffa & $1.67 \mathrm{~b}$ & 50.21 & $1.46 \mathrm{~b}$ & 47.95 & 1.821 & $\mathrm{~b}$ & 67.57 \\
\hline Lagenaria & $3.15 \mathrm{a}$ & 94.61 & $2.68 \mathrm{a}$ & 88.31 & 2.92 & $\mathrm{a}$ & 108.38 \\
\hline C. maxima & $3.31 \mathrm{a}$ & 99.17 & $2.98 \mathrm{a}$ & 98.29 & 2.89 & $\mathrm{a}$ & 107.49 \\
\hline C. moschata & $2.99 \mathrm{a}$ & 89.80 & $1.94 \mathrm{~b}$ & 64.00 & 1.871 & b & 69.42 \\
\hline C. $\max \times C . \operatorname{mos} \mathrm{F}_{1}$ & $2.22 \mathrm{~b}$ & 66.53 & $2.52 \mathrm{a}$ & 83.13 & 1.701 & $\mathrm{~b}$ & 63.27 \\
\hline Control & $3.33 \mathrm{a}$ & 100.00 & $3.03 \mathrm{a}$ & 100.00 & 2.69 & $\mathrm{a}$ & 100.00 \\
\hline \multicolumn{8}{|c|}{ Fruit number per plant No. } \\
\hline Luffa & $13.0 \mathrm{~b}$ & 81.79 & $12.1 \mathrm{c}$ & 71.54 & 13.7 & $\mathrm{~d}$ & 96.91 \\
\hline Lagenaria & $15.7 \mathrm{ab}$ & 98.95 & $17.3 \mathrm{ab}$ & 102.69 & 17.81 & $\mathrm{bc}$ & 125.74 \\
\hline C. maxima & $19.1 \mathrm{a}$ & 120.53 & $17.9 \mathrm{ab}$ & 106.06 & 16.91 & $\mathrm{~b}$ & 119.61 \\
\hline C. moschata & $13.5 \mathrm{~b}$ & 85.26 & $16.3 \mathrm{~b}$ & 96.76 & 14.5 & $\mathrm{~cd}$ & 102.64 \\
\hline C. $\max \times C . \operatorname{mos} \mathrm{F}_{1}$ & $19.2 \mathrm{a}$ & 121.07 & $19.3 \mathrm{a}$ & 114.28 & 19.7 & $\mathrm{a}$ & 139.57 \\
\hline Control & $15.8 \mathrm{~b}$ & 100.00 & $16.9 \mathrm{~b}$ & 100.00 & 14.1 & $\mathrm{~cd}$ & 100.00 \\
\hline \multicolumn{8}{|c|}{ Fruit weight g } \\
\hline Luffa & $210.3 \mathrm{c}$ & 81.09 & $232.5 \mathrm{~ns}$ & 101.59 & 220.61 & $\mathrm{~b}$ & 91.18 \\
\hline Lagenaria & $254.6 \mathrm{a}$ & 98.19 & $237.8 \mathrm{~ns}$ & 103.87 & 221.4 & $\mathrm{~b}$ & 91.51 \\
\hline C. maxima & $234.7 \mathrm{~b}$ & 90.50 & $240.0 \mathrm{~ns}$ & 104.83 & 235.0 & $\mathrm{ab}$ & 97.13 \\
\hline C. moschata & $250.1 \mathrm{a}$ & 96.43 & 245.4 ns & 107.19 & 241.5 & $\mathrm{a}$ & 99.79 \\
\hline C. $\max \times C . \operatorname{mos} \mathrm{F}_{1}$ & $225.1 \mathrm{~b}$ & 86.80 & 230.4 ns & 100.64 & 238.5 & $\mathrm{a}$ & 98.57 \\
\hline Control & $259.3 \mathrm{a}$ & 100.00 & 228.9 ns & 100.00 & 242.0 & $\mathrm{a}$ & 100.00 \\
\hline
\end{tabular}

a, b, c... - Duncan's multiple range test $(P \leq 0.05)$; ns - not significant

The best results for $\mathrm{cv}$. 'Mina $\mathrm{F}_{1}$ ' were obtained after grafting on C. maxima $\times C$. moschata $\mathrm{F}_{1}(6.21 \mathrm{~kg}$ $\left.\mathrm{m}^{-2}\right)$, C. maxima $\left(6.18 \mathrm{~kg} \mathrm{~m}^{-2}\right)$ and Lagenaria $(6.11 \mathrm{~kg}$ $\left.\mathrm{m}^{-2}\right)$. The lowest yield was recorded in all treatments grafted on Luffa. The earliness of cv. 'Mirey $\mathrm{F}_{1}$ ' indicated the highest yields from first five harvests in the control treatment $\left(3.33 \mathrm{~kg} \mathrm{~m}^{-2}\right)$ and treatments grafted on Lagenaria $\left(3.15 \mathrm{~kg} \mathrm{~m}^{-2}\right)$, C. maxima $\left(3.31 \mathrm{~kg} \mathrm{~m}^{-2}\right)$ and C. moschata $\left(2.99 \mathrm{~kg} \mathrm{~m}^{-2}\right)$. The highest early yield of $\mathrm{cv}$. 'Kiara $\mathrm{F}_{1}$ ' was established in the control treatment and treatments grafted on Lagenaria, C. maxima, C. maxima $\times C$. moschata $\mathrm{F}_{1}$. Cultivar 'Mina $\mathrm{F}_{1}$ ' responded with the best results for the control treatment and treatments grafted on Lagenaria and C. maxima. As a whole, the data indicated that the control treatment and treatments grafted on Lagenaria and C. maxima from all treatments possessed the highest earliness.

The highest fruit number per plant was recorded in the three cucumber cultivars grafted on C. maxima $\times$ C. moschata $\mathrm{F}_{1}$ rootstock (19.2, 19.3 and 19.7). Cultivars 'Mirey $\mathrm{F}_{1}$ ' and 'Kiara $\mathrm{F}_{1}$ ' grafted on Lagenaria (15.7 and 17.3) and C. maxima (19.1 and 17.9) also formed significantly high number of fruits per plant. The greatest fruit weight of cv. 'Mirey F' was established in treatments grafted on Lagenaria (254.6 g), C. moschata (250.1 g) and the control $(259.3 \mathrm{~g})$. The differences between the studied treatments of grafting of cv. 'Kiara $\mathrm{F}_{1}$ ' were not proven. Cultivar 'Mina $\mathrm{F}_{1}$ ' had the heaviest fruits in the treatments grafted on C. moschata $(241.5 \mathrm{~g})$, C. maxima $\times$ C. moschata $\mathrm{F}_{1}(238.5 \mathrm{~g})$ and in the control $(242.0 \mathrm{~g})$. These results indicate that scion cultivars react specifically to individual rootstocks. Higher yield, greater earliness, large fruits or great fruit number could be obtained by appropriate scion and rootstock combinations.

Significant differences between the studied treatments on nine sensory characteristics were indicated (Table 3). The highest value of the total sensory evaluation (4.2) was recorded in treatment cv. 'Mirey $\mathrm{F}_{1}$ ' grafted on
Luffa but the differences were not proved compared to the control treatment. The highest values for the most traits were found in the control treatment. The hybrid combination $C$. maxima $\times C$. moschata $\mathrm{F}_{1}$ was with lower sensory quality which was due to the low values of the characters appearance (3.8) and taste (4.0). Insignificant differences were found for characters fruit colour, texture and bitterness.

Control treatment of $\mathrm{cv}$. 'Kiara $\mathrm{F}_{1}$ ' possessed the best sensory characteristics of the fruits. The total sensory evaluation was significantly higher for the fruits from treatments grafted on Luffa, Lagenaria and C. maxima $\times C$. moschata $\mathrm{F}_{1}$ rootstocks (4.1). The taste evaluation varied between control treatment (4.3) and treatments of Lagenaria, C. maxima, C. maxima $\times C$. moschata $\mathrm{F}_{1}$ (4.0) and C. moschata (3.9). Significant differences in the texture between control treatment (4.3) and treatments of C. maxima and C. moschata (4.0) were established. Good appearance was recorded for all treatments (4.0 and 4.1) except for plants grafted on Luffa (3.8). There were no significant differences in fruit colour, flesh colour, cavity presence and bitterness.

Cultivar 'Mina $\mathrm{F}$ ' reacted specifically to the studied sensory traits. Significant differences of the total sensory evaluation between control treatment (4.2) and plants grafted on Luffa (4.0) were established. The taste was better in the control treatment (4.3) than in the plants grafted on Lagenaria and C. moschata (4.0). The texture evaluation was higher in the control treatment (4.3) and lower in the plants grafted on Lagenaria (4.0). There were no significant differences concerning fruit colour, flesh colour and bitterness. The results of the sensory analysis showed specific interaction between the studied scions and rootstocks. Non-grafted plants possessed higher sensory ratings compared to all grafted treatments. For this reason, each grafting combination should be assessed by its similarity in sensory characteristics toward the control treatment. 
Table 3. Sensory evaluation on grafted and non-grafted plants

\begin{tabular}{|c|c|c|c|c|c|c|c|c|c|}
\hline $\begin{array}{c}\text { Scion / } \\
\text { rootstock }\end{array}$ & Appearance & $\begin{array}{c}\text { Fruit } \\
\text { colour }\end{array}$ & Aroma & $\begin{array}{l}\text { Flesh } \\
\text { colour }\end{array}$ & Cavity & Texture & $\begin{array}{c}\text { Bitter- } \\
\text { ness }\end{array}$ & Taste & $\begin{array}{c}\text { Total sensory } \\
\text { evaluation }\end{array}$ \\
\hline \multicolumn{10}{|c|}{ 'Mirey F', } \\
\hline Luffa & $3.8 \mathrm{~b}$ & $3.9 \mathrm{~b}$ & $4.3 \mathrm{a}$ & $4.4 \mathrm{~ns}$ & $4.7 \mathrm{a}$ & $4.3 \mathrm{~ns}$ & $4.8 \mathrm{~ns}$ & $4.3 \mathrm{a}$ & $4.2 \mathrm{a}$ \\
\hline Lagenaria & $4.2 \mathrm{a}$ & $4.1 \mathrm{ab}$ & $4.3 \mathrm{ab}$ & $4.5 \mathrm{~ns}$ & $4.6 \mathrm{ab}$ & $4.1 \mathrm{~ns}$ & $4.8 \mathrm{~ns}$ & $4.0 \mathrm{~b}$ & $4.1 \mathrm{ab}$ \\
\hline C. maxima & $3.9 \mathrm{~b}$ & $4.0 \mathrm{ab}$ & $4.1 \mathrm{~b}$ & $4.5 \mathrm{~ns}$ & $4.7 \mathrm{a}$ & $4.2 \mathrm{~ns}$ & $4.8 \mathrm{~ns}$ & $4.1 \mathrm{ab}$ & $4.1 \mathrm{ab}$ \\
\hline C. moschata & $4.0 \mathrm{ab}$ & $4.0 \mathrm{ab}$ & $4.3 \mathrm{ab}$ & $4.4 \mathrm{~ns}$ & $4.5 \mathrm{~b}$ & $4.1 \mathrm{~ns}$ & $4.9 \mathrm{~ns}$ & $4.0 \mathrm{~b}$ & $4.1 \mathrm{ab}$ \\
\hline C. $\max \times C . \operatorname{mos} \mathrm{F}_{1}$ & $3.8 \mathrm{~b}$ & $4.0 \mathrm{ab}$ & $4.1 \mathrm{ab}$ & $4.6 \mathrm{~ns}$ & $4.7 \mathrm{a}$ & $4.1 \mathrm{~ns}$ & $4.9 \mathrm{~ns}$ & $4.0 \mathrm{~b}$ & $4.0 \mathrm{~b}$ \\
\hline Control & $4.2 \mathrm{a}$ & $4.2 \mathrm{a}$ & $4.3 \mathrm{ab}$ & $4.5 \mathrm{~ns}$ & $4.7 \mathrm{ab}$ & $4.1 \mathrm{~ns}$ & $4.9 \mathrm{~ns}$ & $4.1 \mathrm{ab}$ & $4.1 \mathrm{ab}$ \\
\hline \multicolumn{10}{|c|}{ 'Kiara F' } \\
\hline Luffa & $3.8 \mathrm{~b}$ & $4.0 \mathrm{~ns}$ & $4.2 \mathrm{ab}$ & $4.5 \mathrm{~ns}$ & $4.7 \mathrm{~ns}$ & $4.3 \mathrm{ab}$ & $4.8 \mathrm{~ns}$ & $4.1 \mathrm{ab}$ & $4.1 \mathrm{ab}$ \\
\hline Lagenaria & $4.1 \mathrm{a}$ & $4.2 \mathrm{~ns}$ & $4.3 \mathrm{ab}$ & $4.5 \mathrm{~ns}$ & $4.6 \mathrm{~ns}$ & $4.1 \mathrm{ab}$ & $4.8 \mathrm{~ns}$ & $4.0 \mathrm{~b}$ & $4.1 \mathrm{ab}$ \\
\hline C. maxima & $4.0 \mathrm{ab}$ & $4.1 \mathrm{~ns}$ & $4.1 \mathrm{~b}$ & $4.4 \mathrm{~ns}$ & $4.6 \mathrm{~ns}$ & $4.0 \mathrm{~b}$ & $4.9 \mathrm{~ns}$ & $4.0 \mathrm{~b}$ & $4.0 \mathrm{~b}$ \\
\hline C. moschata & $4.0 \mathrm{ab}$ & $4.1 \mathrm{~ns}$ & $4.2 \mathrm{ab}$ & $4.5 \mathrm{~ns}$ & $4.6 \mathrm{~ns}$ & $4.0 \mathrm{~b}$ & $4.7 \mathrm{~ns}$ & $3.9 \mathrm{~b}$ & $4.0 \mathrm{~b}$ \\
\hline C. $\max \times C . \operatorname{mos} \mathrm{F}_{1}$ & $4.1 \mathrm{a}$ & $4.1 \mathrm{~ns}$ & $4.2 \mathrm{~b}$ & $4.4 \mathrm{~ns}$ & $4.6 \mathrm{~ns}$ & $4.2 \mathrm{ab}$ & $4.8 \mathrm{~ns}$ & $4.0 \mathrm{~b}$ & $4.1 \mathrm{ab}$ \\
\hline Control & $4.1 \mathrm{a}$ & $4.2 \mathrm{~ns}$ & $4.4 \mathrm{a}$ & $4.6 \mathrm{~ns}$ & $4.6 \mathrm{~ns}$ & $4.3 \mathrm{a}$ & $4.9 \mathrm{~ns}$ & $4.3 \mathrm{a}$ & $4.3 \mathrm{a}$ \\
\hline \multicolumn{10}{|c|}{ 'Mina $F_{1}$ ' } \\
\hline Luffa & $3.9 \mathrm{~b}$ & $3.9 \mathrm{~ns}$ & $4.2 \mathrm{~b}$ & $4.5 \mathrm{~ns}$ & $4.8 \mathrm{ab}$ & $4.1 \mathrm{ab}$ & $4.9 \mathrm{~ns}$ & $4.0 \mathrm{ab}$ & $4.0 \mathrm{~b}$ \\
\hline Lagenaria & $4.1 \mathrm{ab}$ & $4.1 \mathrm{~ns}$ & $4.3 \mathrm{ab}$ & $4.6 \mathrm{~ns}$ & $4.8 \mathrm{a}$ & $4.0 \mathrm{~b}$ & $4.8 \mathrm{~ns}$ & $4.0 \mathrm{~b}$ & $4.1 \mathrm{ab}$ \\
\hline C. maxima & $3.9 \mathrm{~b}$ & $4.0 \mathrm{~ns}$ & $4.1 \mathrm{~b}$ & $4.4 \mathrm{~ns}$ & $4.7 \mathrm{abc}$ & $4.1 \mathrm{ab}$ & $4.9 \mathrm{~ns}$ & $4.1 \mathrm{ab}$ & $4.0 \mathrm{ab}$ \\
\hline C. moschata & $4.2 \mathrm{~b}$ & $4.2 \mathrm{~ns}$ & $4.1 \mathrm{~b}$ & $4.5 \mathrm{~ns}$ & $4.5 \mathrm{c}$ & $4.1 \mathrm{ab}$ & $4.9 \mathrm{~ns}$ & $4.0 \mathrm{~b}$ & $4.0 \mathrm{ab}$ \\
\hline C. $\max \times C . \operatorname{mos} \mathrm{F}_{1}$ & $3.8 \mathrm{~b}$ & $3.9 \mathrm{~ns}$ & $4.4 \mathrm{a}$ & $4.5 \mathrm{~ns}$ & $4.7 \mathrm{abc}$ & $4.1 \mathrm{ab}$ & $4.8 \mathrm{~ns}$ & $4.1 \mathrm{ab}$ & $4.1 \mathrm{ab}$ \\
\hline Control & $4.1 \mathrm{ab}$ & $4.1 \mathrm{~ns}$ & $4.4 \mathrm{a}$ & $4.5 \mathrm{~ns}$ & $4.6 \mathrm{bc}$ & $4.3 \mathrm{a}$ & $4.9 \mathrm{~ns}$ & $4.3 \mathrm{a}$ & $4.2 \mathrm{a}$ \\
\hline
\end{tabular}

a, b, c...-Duncan's multiple range test $(P \leq 0.05)$. ns - not significant

Cluster analysis, made on the basis of nine sensory traits, showed that the studied treatments of cv. 'Mirey $\mathrm{F}_{1}$ ' were composed of two groups of similarity (Fig.). The treatments of Lagenaria, Luffa and the control were in the first group. The second group combined the remaining treatments $C$. maxima, C. moschata and C. maxima $\times$ C. moschata $\mathrm{F}_{1}$.

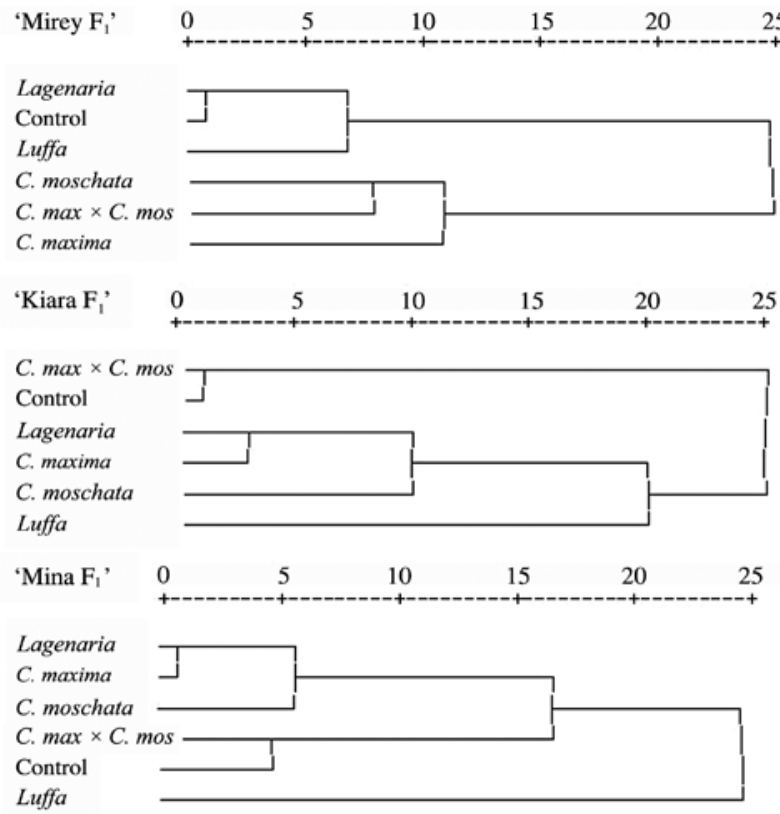

Figure. Cluster analysis on the basis of nine sensory characters

According to the dendrogram for $\mathrm{cv}$. 'Kiara $\mathrm{F}_{1}$ ', the treatments were divided into three groups of similarity. The first group contained the control treatment and $C$. maxima $\times C$. moschata $\mathrm{F}_{1}$. The second group was included C. maxima, C. moschata and Lagenaria. The separate treatment with grafting on Luffa was in the third group. The treatments of cv. 'Mina $\mathrm{F}_{1}$ ' also formed three groups of similarity. The treatments on Lagenaria, $C$. maxima and $C$. moschata were in the first group. The second group included the control treatment and C. maxima $\times$ C. moschata $\mathrm{F}_{1}$. The treatment grafted on Luffa was in another group.
According to the cluster analysis, on the sensory profile the greatest similarity toward the control cv. 'Mirey F' possessed the treatments grafted on Lagenaria and Luffa. The control treatments cvs. 'Kiara $\mathrm{F}_{1}$ ' and 'Mina $\mathrm{F}_{1}$ ' were similar to $C$. maxima $\times$ C. moschata $\mathrm{F}_{1}$.

\section{Discussion}

The yield is one of the most important factors in determining the most appropriate combination between scion and rootstock. The yield is a variable trait which could be influenced by the variety of scion, species of rootstock and environmental conditions $\mathrm{G} \times \mathrm{G} \times \mathrm{E}$ (King et al., 2010). Our results confirm this statement. We established that the power of influence of each factor responsible for variation of total yield was different. The year predominantly influenced the variation of the yield $(\eta \%=55.78)$, i.e. specific environmental conditions (Table 1). The second important factor was rootstock ( $\eta \%$ $=16.97)$. The scion affected variation of yield with $\eta \%=$ 1.61. This means that rootstock is a more important factor compared to the scion. In some years certain combinations of scion/rootstock could realize a higher yield. These data explain the contradictory results of a number of authors who indicate different scion and rootstock combinations. Earliness is the main index which demonstrates the significant role of the rootstock. Farhadi and Malek (2015) confirm that the earliness of grafted cucumber is affected by the rootstock. In our experiment, the rootstock was also the most significant factor that affects the variation of earliness. The elements of productivity had a specific reaction to the studied factors. The variation of number of fruits per plant was affected more strongly by rootstock $(\eta \%=16.51)$, year $(\eta \%=57.34)$ and their interaction $(\eta \%=11.22)$. For example, in different years certain rootstocks could achieve a larger number of fruits compared to the other ones. The used scion played insignificant role for determining the number of fruits per plant. This is of practical importance in testing of a large number of scion/rootstock combinations. The obtained results reveal the capabilities of rootstock regardless of the cucumber scion varieties.

Our results are in agreement with those of Zijlstra et al. (1994) who tested 24 grafting combinations between different cucumbers. According to their results, no interaction was found between scion and rootstock effects with respect to fruit number per cucumber plant. 
It is possible to established differences in different rootstocks on the basis of the same scion genotype.

The fruit weight varied depending on rootstock $(\eta \%=18.59)$ as well as on interaction between scion and rootstock $(\eta \%=20.55)$. Certain combinations could have lighter or heavier fruits and it also depended on rootstock and year interaction $(\eta \%=15.17)$.

The amount of the yield was determined in greater extent by average fruit number per plant in comparison with the average fruit weight. These results corroborate those obtained by Seong et al. (2003) and AlDebei et al. (2012) where an increase of yield is mainly due to the increase in number of fruit per plant rather than the increase in average fruit weight.

Hoyos (2001) and Farhadi and Rezaie (2015) have indicated that the productivity depends in greater extent on the rootstock compared to the scion which agrees with the results of our study. Lee (1994) reported that the effect could be even negative and cause a decrease in the yield. The effect of grafting cv. 'Mirey $F_{1}$ ' was not well expressed and the yield differences were minimal (Table 2). The highest yield of $\mathrm{cv}$. 'Kiara $\mathrm{F}_{1}$ ' was achieved in plants grafted on C. maxima and C. maxima $\times$ C. moschata $\mathrm{F}_{1}$. Cultivar 'Mina $\mathrm{F}_{1}$ ' also reacted positively when plants were grafted on rootstocks of Lagenaria, $C$. maxima and $C$. maxima $\times C$. moschata $\mathrm{F}_{1}$ and the yields considerably exceeded the control treatment. This is in accordance with the results recorded by Pavlou et al. (2002) and Abd El-Wanis et al. (2013) where grafted cucumber plants produced significantly high yield than non-grafted one.

The lowest yield was obtained in the treatments grafted on Luffa. Similar results were received by Hernandez-Gonzalez et al. (2014) on pumpkin and fig leaf gourd rootstocks with a significant increase in cucumber yield while the Luffa rootstock showed a negative effect. This could be interpreted by weak development of it root system. Davis et al. (2008 a) summarized that yield of plants with weak rootstocks is lower compared to the yield with vigorous ones. Even if plants with weak rootstocks are spaced widely and grown in fertile conditions, their yields are still low, due to few fruit per plant.

Under our conditions earliness was less or equal expressed in treatments with grafting than in each control treatments (cvs. 'Mirey F', 'Kiara $\mathrm{F}_{1}$ ' and 'Mina $\mathrm{F}_{1}$ '). According to Hoyos (2001), grafting reduces precocity. In contrast, Cansev and Ozgur (2010) and Farhadi and Malek (2015) established that rootstocks affected positively fruit earliness.

The average fruit number per plant indicated significant variation between the studied treatments. Particularly plants grafted on C. maxima $\times C$. moschata $\mathrm{F}_{1}$, C. maxima and Lagenaria produced the highest fruit number per plant compared to the control and other treatments. Similar results were obtained by Seong et al. (2003).

In our study, fruit weight varied depending on scion and rootstock. The differences were insignificant in treatments of cv. 'Kiara $\mathrm{F}^{\text {' }}$ only. The results were contradictory. The similar results were obtained by other authors. Grafting either had no influence on the fruit weight (Marsic, Jakse, 2010; Farhadi, Malek, 2015) or had positive effect (Heidari et al., 2010).

As a result of the studied traits, the best rootstocks for cv. 'Mirey $\mathrm{F}_{1}$ ' were Lagenaria and C. maxima, for cv. 'Kiara $\mathrm{F}_{1}$ ' $-C$. maxima $\times C$. moshata $\mathrm{F}_{1}$ and $C$. maxima, and for $\mathrm{cv}$. 'Mina $\mathrm{F}_{1}$ ' - C. maxima $\times C$. moschata $\mathrm{F}_{1}$, C. maxima and Lagenaria.

The question about fruit quality and grafting still remains under consideration. Most reports on grafting suggest that changes in the scion are controlled by the rootstock through controlled uptake, synthesis, and translocation of water, minerals and plant hormones (Davis et al., 2008 b). In general, in cucurbit crops the effects of rootstock on fruit quality are often negative (Lee, 1994; Lee et al., 2010). According to Hoyos (2001), grafting has no effect on the quality, taste, size and shape of the fruit

The results clearly show that an optimal combination of sensory characteristics of cucumber fruits depending on treatment of grafting could be obtained. It is obviously that every scion cultivar reacts in different way toward the same rootstock. This means that the choice of combinations between scion cultivar and rootstock species should be determined after preliminary studies of both components.

\section{Conclusions}

1. Different rootstocks play an important role in cucumber productivity and quality. The most adequate rootstocks that we proposed are Cucurbita maxima $\times$ C. moschata F (cv. 'Carnivor'), Lagenaria (landrace) and C. maxima ('Plovdivski', old local cultivar).

2. The choice of combinations between scion cultivar and rootstock species should be determined after preliminary studies of both components.

3. Regardless of the popularity of hybrid C. maxima $\times C$. moschata $\mathrm{F}_{1}$, we believe that the other studied cucurbit species are promising sources for developing new rootstock cultivars.

4. The studied rootstocks could be of great importance in initiating a new breeding programme which is based on local cucurbit germplasm.

\section{Acknowledgements}

We express our thanks to the Syngenta Ltd. for kindly providing seeds from rootstock cv. 'Carnivor' (C. maxima $\times$ C. moshata $\mathrm{F}_{1}$ ).

Received 27052016 Accepted 13092016

\section{References}

Abd El-Wanis M. M., Amin A. W., Tomader G. A. R. 2013. Evaluation of some Cucurbitaceous rootstocks 2-effect of cucumber grafting using some rootstocks on growth, yield and its relation with root-knot nematode Meloidogyne incognata and Fusarium wilt, infection. Egyptian Journal of Agricultural Research, 91 (1): 235-257

Agrostatistic. 2014. Ministry of Agriculture and Food, Republic of Bulgaria <http:// www.mzh.government.bg $>$

Al-Debei H. S., Makhadmeh I., Abu-Al Ruz I., AlAbdallat A. M., Ayad J. Y., Al Amin N. 2012. Influence of different rootstocks on growth and yield of cucumber (Cucumis sativus L.) under the impact of soil-borne pathogens in Jordan. Journal of Food, Agriculture and Environment, $\quad 10$ (2): 343-349

Cansev A., Ozgur M. 2010. Grafting cucumber seedlings on Cucurbita spp.: comparison of different grafting methods, scions and their performance. Journal of Food, Agriculture and Environment, 8 (3-4): 804-809

Colla G., Rouphael Y., Rea E., Cardarelli M. 2012. Grafting cucumber plants enhance tolerance to sodium chloride and sulfate salinization. Scientia Horticulturae, 135: 177-185 http://dx.doi.org/10.1016/j.scienta.2011.11.023

Davis A. K., Perkins-Veazie P., Sakata Y., López-Galarza S., Maroto J. V., Lee S. G., Huh Y. C., Sun Z., Miguel A., King S. R., Cohen R., Lee, J. M. 2008 (a). Cucurbit grafting. Critical Reviews in Plant Sciences. 27: 50-74 http://dx.doi.org/10.1080/07352680802053940

Davis A. K., Perkins-Veazie P., Hassell R., Levi A., King S. R., Zhang X. 2008 (b). Grafting effects on vegetable quality. HortScience, 43 (6): 1670-1672

Farhadi A., Malek S. 2015. Evaluation of graft compatibility and organoleptic traits of greenhouse cucumber seedlings 
grafted on different rootstocks. Proceedings of the Acta Horticulturae. 1086: 219-224

http://dx.doi.org/10.17660/ActaHortic.2015.1086.27

Farhadi A., Rezaie M. 2015. Evaluation of quantitative and qualitative traits of greenhouse cucumber (Cucumis sativus L. 'Khassib') grafted on different Cucurbita rootstocks. Proceedings of the Acta Horticulturae 1086. 779-7.84 http://dx.doi.org/10.17660/ActaHortic.2015.1086.35

Heidari A. A., Kashi A., Satfari Z., Kalatejari S. 2010. Effect of different Cucurbita rootstocks on survival rate, yield and quality of greenhouse cucumber cv. Khassib. Plant Ecophysiology, 2: 115-120

Hernandez-Gonzalez Z., Sahagun-Castellanos J., EspinosaRobles P., Colinas-León M. T. J., Rodríguez-Perez E. 2014. Effect of rootstock on yield and fruit size in grafted cucumber. Revista Fitotecnia Mexicana, 37 (1): 41-47

Hoyos P. 2001. Influence of different rootstocks on the yield and quality of greenhouses grown cucumbers. Acta Horticulturae 559: 139-143

http://dx.doi.org/10.17660/ActaHortic.2001.559.19

Huang Y., Iang R., Cao Q., B1e Z. 200Y. Improving the truit yield and quality of cucumber by grafting onto the salt tolerant rootstock under NaCl stress Scientia Horticulturae 1?? (1): 26-31 http://dx.doi.org/10.1016/j.scienta.2009.04.004

Huang Y., Bie Z., He S., Hua B., Zhen A., Liu Z. 2010. Improving cucumber tolerance to major nutrients induced salinity by grafting onto Cucurbita ficifolia. Environmental and Fxnerimental Rotany. 69: 32-38 http://dx.doi.org/10.1016̆/j.envexpbot.2010.02.002

King St. R., Davis A.K., Zhang X., C'rosby K. 2010. Genetics, breeding and selection of rootstocks for Solanaceae and Cucurhitacene Scientia Horticulturae, 127: 106-111 http://dx.doi.org/10.1016/j.scienta.2010.0́8.001

Lee J. M. 1994. Cultivation of grafted vegetables. Current status, grafting methods, and benefits. Horticultural Science, 29: 235-239

Lee J., Bang H., Ham H. 1999. Quality of cucumber fruit as affected hy rontstock. Acta Horticulturae, 483: 117-124 http://dx.dooi.org/10.17660/ActaHortic.1999.483.12

Lee J. M., Kubota C., Isao S. J., Bie Z., Hoyos E. P., Morra L., Oda M. 2010. Current status of vegetable grafting: diffusion, grafting techniques, automation. Scientia Horticulturae $127 \cdot 93-105$

http://dx.doi.org/10.1016/j.scienta.2010.08.003

Lidanski I. 1988. Statistical methods in biology and agriculture. Sofia, Bulgaria, 375 p. (in Bulgarian)
Marsic N. K., Jakse M. 2010. Growth and yield of grafted cucumber (Cucumis sativus L.) on different soilless substrates. Journal of Food, Agriculture and Environment, $8(2): 654-658$

Moradipour F., Dashti F., Zahedi B. 2010. Effect of grafting on yield and some vegetative characteristics of two greenhouse cucumber cultivar. Iranian Journal of Horticultural Science, 41 (3): 291-300

Oda M. 2002. Grafting of vegetable crops. Scientific Report of Agriculture and Biological Sciences, Osaka Prefecture University, 54: 49-72

Pavlou G., Vakalounakis D., Ligoxigakis E. 2002. Control of root and stem rot of cucumber, caused by Fusarium oxysporum $\mathrm{f}$. sp. radicis-cucumerinum, by grafting onto resistant rontstocks. Plant Disease, 86: 379-382 http://dx.doi.org/10.1094/PDIS.2002.86.4.379

Sakata Y., Ohara T., Sugiyama M. 2007. The history and present state of the grafting of Cucurbitaceous vegetables in Japan. Acta Horticulturae 731 159-170

http://dx.doi.org/10.17660/ActaHortic.2007.731.22

Sakata Y., Ohara T., Sugiyama M. 2008. The history of melon and cucumber grafting in Janan. Acta Horticulturae, 767: 217-228 http://dx.doi.org/10.17660/ActaHortic.2008.767.22

Schwarz D., Kouphael Y., Colla G., Venema J. H. 2010. Grafting as a tool to improve tolerance of vegetables to abiotic stresses: thermal stress, water stress and organic nollutants. Scientia Horticulturae, 127: 162-171 http://dx.doi.org/10.1016/j.scienta.2010.09.016

Seong K. C., Moon J. M., Lee S. G., Kang Y. G., Kim K. Y., Seo H. D. 2003. Growth, lateral shoot development, and fruit yield of white-spined cucumber (Cucumis sativus cv. Baekseong-3) as affected by grafting methods. Journal of the Korean Society for Horticultural Science, 44: 478-482

Sonneveld C. 1990. Estimating quantities of water-soluble nutrients using a specific $1: 2$ by volume extract. Soil Science and Plant Analysis, 21 (13-16): 1257-1265 http://dx.doi.org/10.1080/00103629009368303

Uysal N., 'Tuzel Y., Oztekin G. B., Tuzel I. H. 2012. Effects of different rootstocks on greenhouse cucumber production. Acta Horticulturae 927:281-289

http://dx.doi.org/10.17660/ActaHortic.2012.927.32

Zijlstra S., Groot S. P. C., Jansen J. 1994. Genotypic variation of rootstocks for growth and production in cucumber; possibilities for improving the root system by plant hreeding. Scientia Horticulturae, 56 (3): 185-196 http://dx.doi.org/10.1016/0304-4238(94)90001-9

ISSN 1392-3196 / e-ISSN 2335-8947

Zemdirbyste-Agriculture, vol. 103, No. 4 (2016), p. 405-410

DOI $10.13080 / \mathrm{z}-\mathrm{a} .2016 .103 .052$

\title{
Skiepijimo įtaka agurkų derliui ir juslinėms savybẻms
}

\author{
N. Velkov, G. Pevicharova \\ Daržovių tyrimų institutas „Maritsa“, Bulgarija
}

\section{Santrauka}

Agurkų skiepijimo įtaka vaisių derliui ir juslinėms savybėms buvo tirta šiltnamio sąlygomis 2014-2015 m. Trys ilgavaisių partenokarpinių agurkų veislès buvo skiepijamos ị penkių Cucurbita ir Lagenaria genčių augalus. Tyrimo tikslas - palyginti derlių, produktyvumo elementus ir agurkų vaisių juslines savybes, siekiant nustatyti pačius tinkamiausius įskiepių / poskiepių derinius. Didžiausias derlius buvo nustatytas derinio, kai veislès 'Kiara $\mathrm{F}_{1}$ ' agurkai buvo ịskiepyti i hibridą Cucurbita maxima $\times$ C. moschata $\mathrm{F}_{1}$. Poskiepiai Lagenaria bei C. maxima ir kontrolinis variantas paankstino agurkų derejimą. Poskiepis $C$. maxima $\times C$. moschata $\mathrm{F}_{1}$ davè didžiausią kieki agurkų vaisių iš augalo. Priklausomai nuo ịskiepio / poskiepio derinių, vaisių juslinès savybės - išvaizda, kvapas, skonis ir bendras juslinis ịvertinimas - esmingai skyrèsi. C. maxima $\times$ C. moschata F1, Lagenaria ir C. maxima poskiepiai buvo gerai suderinami su tirtomis agurkų veislemis. İskiepių / poskiepių deriniai turètų būti parinkti atlikus išankstinius abiejų komponentų tyrimus.

Reikšminiai žodžiai: Cucumis sativus, išvaizda, skonis, tekstūra, vaisių skaičius, vaisių svoris.

Please use the following format when citing the article:

Velkov N., Pevicharova G. Effects of cucumber grafting on yield and fruit sensory characteristics. ZemdirbysteAgriculture, 103 (4): 405-410 DOI 10.13080/z-a.2016.103.052 